has left these banks in relief, and the amount of this wastage is indicated by the Holme post, which proves that Whittlesea Mere is about $11 \mathrm{ft}$. lower than in 1848. The co-operation of workers in many fields has been secured, and much attention given to the botany, geology and zoology of the region, which is linked to North Germany and Scandinavia by its foraminifera and tree-pollen, to say nothing of changes in relation to sea-level. The work supervised by Dr. Grahame Clark in association with Mr. C. W. Phillips and Major Fowler has been rendered more difficult by the presence of water in the deeper cuttings; but funds have been provided, mainly by the Percy Sladen Memorial Fund, and the present exhibition, which will be open at least two months, will reveal to a larger public the potentialities of the Fens as a field of research in various branches of science.

\section{Iron Age Site on the Sussex Weald}

A FURTher addition to the sites of industrial activity in Sussex in later prehistoric and Roman times, for which archæologists are indebted to the activity in investigation of $\mathrm{Mr}$. S. E. Winbolt, is made by the discovery of an Early Iron Age camp on the Weald in Piper's Copse, one and a quarter miles east of North Chapel, West Sussex. The situation is remote and the discovery was due to the fact that a fox had dug its earth in a dry place where a small iron smelting hearth had been constructed in the inner slope of a bank. This was found on investigation to be the north-west end of an enclosure formed by a bold bank and deepish ditch, in good condition, except on the south-east, where an attempt had been made at levelling. The dimensions of the camp, Mr. Winbolt states in a communication to The Times of August 5, are a little more than $300 \mathrm{ft}$. by $270 \mathrm{ft}$. outside measurement, the inner area comprising about $1 \frac{1}{4}$ acres. The height of the rampart, where best preserved, is $14 \mathrm{ft}$. from the bottom of the ditch. Two points of special interest arise in connexion with this discovery. The camp lies on the Wealden level (c. $120 \mathrm{ft}$.) and although Early Iron Age camps are known on heights fringing the Weald, such as at Holmbury and Hascomb, Saxonbury and Dry Hill, this is the first to be recorded at the Wealden level. The second point of interest is its date and purpose. These are fixed by red burnt material, charcoal, nodules of local iron ore and five fragments of La Tène iii pottery, as well as by many big lumps of iron ore lying near by. The site lies about two miles from the eastern slope of Blackdown near $\mathbf{a}_{\mathbf{a}}$ stream flowing into the Arun and is in the middle of a country rich in iron ore of a moderate quality, where iron furnaces and forges of late medieval date abound, as, for example, at Mitchell Park, Shillinglee, Ebernoe and Roundwyck. Mr. Winbolt points to this as a further instance of the previous existence of Iron Age and Roman iron workings where medieval and Tudor workers are found.

\section{Science and Culture: A new Indian Monthly}

IT was anticipated by the founders of the Indian Science Congress that the Congress would stimulate in India an interest in science and in scientific research. At the time of its formation, the reforms in Indian university education resulting from the recommendations of the Curzon Commission were becoming effective and the universities were beginning to be centres of research. The spirit of scientific inquiry grew during the War period, and if the formation of scientific societies and the issue of scientific journals are to be regarded as criteria of increased interest in science, the hopes of the founders of the Congress have been fulfilled. There are in existence a number of specialist societies, the most recent addition being a Physical Society, and we referred recently $(135,410,441$; March 16,1935$)$ to the foundation of the National Institute of Sciences of India with its affiliated academies, the Asiatic Society of Bengal, the U.P. Academy of Sciences (Allahabad), and the Indian Academy of Science (Bangalore). In so large a country as India it is natural that there should be more than one academy, but the choice of names for these bodies is not happy and is likely to cause confusion in references to their publications.

THE more general aspects of science have in the past been dealt with by the weekly periodical Current Science, and we have now received the first issue of a monthly journal, Science and Culture, published by a non-profit corporation in Calcutta. The object of this periodical "is the dissemination of scientific knowledge amongst the public and advocacy of its application to all walks of life as far as practicable". The first issue contains a number of valuable articles the majority of which deal with topics"of local interest, but the lecture by Prof. M. N. Saha "Ultimate Constituents of Matter" will attract a wider public. There are, in addition, reviews of books and a correspondence column. The latter, containing preliminary accounts of scientific investigations, seems scarcely in keeping with the other contents. These 'letters to the editor' would have appeared more suitably in Current Science. We welcome this new periodical, and if the high standard of the first number be maintained its success is assured.

\section{British Empire Naturalists' Association in Jersey}

IN the official report of the summer meeting of the British Empire Naturalists' Association in Jersey, Mr. Leslie Beckett, honorary organising secretary of the Association, states that many rare plants and birds were observed. Particularly was the island fruitful in flora, and of the more interesting examples noted, mention is made of many plants rare or unknown in England but quite well established and safe in Jersey ; for Jersey is the northern limit of many Continental and North African plants. The English or five-spotted catchfly (Silene gallica) was found in profusion nearly everywhere, and near Crabbe, the party found the rare variety, quinquevulnera, which few of the botanists present had seen before. One party found a big patch of the Jersey bugloss (Echium plantagineum) between St. Brelades and Corbière. On the sand-dunes near Le Pont was found the rare yellow broomrape (Orobanche ritro) which is not found elsewhere between this 
locality and Spain. On the last afternoon of the fortnight, Convoluta Roscoffensis was noted, an extraordinary example of symbiosis between a worm and an alga. Of bird-life, Mr. Le Maître led a party to the cliffs at Crabbe, to photograph the herringgullery there, and the Rev. Pere Burdos led a party to the Pinnacle, a rock $200 \mathrm{ft}$. above sea-level near Plemont, where the peregrine falcon, raven, puffin and nesting guillemots, razorbills and oyster-catchers were seen. The granites in which Jersey is so rich interested the geologists, and while studying a quarry near Gorey Castle the rare hyssop-leaved loosestrife plant was noted. The first meeting of the London branch of the B.E.N.A. will be held at the Furnival Hall, Furnival Street, on October 16, when Mr. J. Ramsbottom will lecture on "Moulds and Mushrooms".

\section{Technical College Buildings}

IT is little less than astonishing that a country like Great Britain, which has been the pioneer in scientific work and retained so high a standard of scientific achievement, should have such a paucity of literature dealing with material needs in the matter of buildings and equipment necessary for its field of activity. Books dealing with laboratories can be counted on the fingers, while for any wide general account of technical institutions dealing with the application of science to the trades, it is necessary to go back nearly half a century. The report, published at the expense of the Carnegie United Kingdom Trust, by a Joint Committee of the Association of Technical Institutions, the Association of Principals of Technical Institutions with representatives of the Royal Institute of British Architects and the Institute of Builders and a member of the staff of the Board of Education is therefore to be specially welcomed, particularly at the present time when the demands for buildings for technical education are so marked (London : Associa. tion of Technical Institutions and the Association of Principals of Technical Institutions, 1935 . 3s.) The volume, consisting of some 150 quarto pages including plans and illustrations, is the work of a representative committee the personnel of which is sufficient evidence of authority. 'The opening two chapters deal with general requirements including service supplies and accommodation, and these are followed by concise articles on the special needs of specific subjects, some twenty in all, embracing such fields as leather industries, printing and textiles in addition to the more generally taught trade principles. These chapters, which occupy the bulk of the volume, have been compiled by panels of experts intimately associated with the required tuition. The brochure concludes with two chapters illustrated with plans and photographs of recent British and Continental examples of buildings, and should be of great value to all concerned with the development and execution of schemes for technical education.

\section{Temperament in Industry}

THE effects of having the wrong type of persons in positions of authority were discussed by Dr. May
Smith, senior investigator to the Industrial Health Research Board, in a lecture on May 27 forming part of a course on the temperamental factor in industry arranged by the National Institute of Industrial Psychology. She said that it was not uncommon to find that a high rate of sickness absences was the result of having a supervisor with the wrong temperament for his job. Sickness is also frequently ascribed to overwork, but overwork itself is often the result of having to deal with the unreasonable demands of heads who are irrational and lack emotional balance. After dealing with various temperamental types who cause trouble when they are in important positions, Dr. May Smith outlined the attributes of a good head. Assuming that he has the necessary intellectual powers and technical knowledge, the first requirement is a sense of justice - a capacity for asking, not "Am I receiving justice ?" but "Am I giving it ?" A good head must create the knowledge that everyone under him will receive fair treatment. A second quality is vitality, explaining that she meant not physical exuberance, which is often exhausting to subordinates, but the controlled energy that inspires them. "The 'Weary Willy' and the 'Streak of Misery'," she said, "should have no place at the head." The next requisite is the ability to regard people and things dispassionately, to see them as they really are, and not merely as they happen to appeal to the man himself. A sense of humour is the next requisite, to prevent the head taking himself too seriously. Finally, the good head must be able to rule without straining his powers on one hand or shirking responsibility on the other. Tem. peramental factors in industry do not receive sufficient attention in Great Britain, and it is a pity employers and departmental managers do not receive training in handling personalities. 'Nagging' might well be made a capital offence !

\section{The Government Laboratory}

Few, apart from those who study the annual report of the Government Chemist, are well acquainted with the character and volume of the work which is carried out at the Government Laboratory. A detailed and illustrated account of the activities of this laboratory has recently been published in the Chemist and Druggist ; since much of the informa. tion which relates to processes and figures has been supplied to the author, the article can be accepted as an accurate and fully informed review. The Department of the Government Chemist, in its capacity of a protector of the revenue, undertakes the routine analysis of large numbers of samples of dutiable goods, handling, for example, some 5,000 samples of tobacco every week. As a public servant assisting in suppressing adulteration, it acts as a referee when reports of public analysts are challenged. The samples concerned have frequently undergone changes by the time they reach the laboratory-this applies particularly to samples of milk-so that the necessary analytical procedure is much more elaborate than normally. Such considerations involve a good deal of research, leading to the working out of satisfactory analytical methods. Another function 